\title{
Intensive Care
}

\author{
Rawinder Singh*, Gina Schlawinwer, Prakash Gupta, Jeff Stryker, Fanny Hill and Gino Frizzante \\ Institute for Sexual Hygiene, India
}

Submission: February 2, 2018; Published: February 26, 2018

*Corresponding author: Rawinder Singh, Institute for Sexual Hygiene, Mumbai, India, Email: Christian.Byhahn@evangelischeskrankenhaus.de

\section{Opinion}

Astrid my wife and I work for a level 1 trauma center in East Tennessee. Our hours are long and grueling. Sometimes we don't get home for days on end. Especially during the summer. The Interstate runs through the city and there are always people harming themselves or others and our ER stays busy 24/7. After three days of on-call Astrid and I had a precious five days off. We literally ran to the car before anyone had a chance to change their mind. We had an hour and a half drive ahead of us, the sun was going down and the AC was on full blast. Astrid said she wanted to stop for coffee on the way, so just before hitting the six-lane we stopped at the dinner and got two cups to go. Once I emerged I realized how dark it was and I stumbled across the gravel parking lot and when I got back to the car, I set the cups on the roof, opened the door and grabbed the cups and went to set them in the cup holders.

To my pleasant surprise, Astrid was sitting there in the seat naked as the day she was born. Astrid gave me a wicked smile. She said...."I'm tired, I'm horny and I'm hot. Take the long way...we don't have to be anywhere for five days any certain time." Never one to disappoint Astrid I quickly agreed, wondering just exactly what the hell she had in mind. Didn't take me long to find out. Astrid levered her seat into a reclining position and her left hand went to her luscious pussy and her right went to her beautiful firm breasts. Astrid moved her left hand slowly and languidly caressing her moist folds and clit. A few minutes later her left hand began moving faster and then she plunged two fingers deep inside of her, I heard her gasp with pleasure as she finger fucked herself, she must have been soaking wet because I could hear the wet sounds as she fucked herself. Then she moved to her clit and began stroking and pinching the sensitive little bud.

Suddenly Astrid sighed and her hips bucked upwards and began pistoning up and down until she moaned long and low and she sank back in her seat still trembling with the power of her orgasm, she gasped for several minutes and then became quiet. Have to admit, my cock was rock hard. Astrid began to masturbate again. She orgasmed two more times. By now my mind was reeling with pure lust. Astrid leaned over and whispered in my right ear..." baby pull over I want you to give me a mouthful of cum"
I found the first wide spot and as soon as I slowed Astrid was pulling at my scrub pants. She turned and kneeled in her seat and wrapped a hand around my throbbing cock. She opened her mouth and took my entire length in one movement. Astrid sucked and slobbered on my cock until I exploded in her mouth. Astrid began swallowing greedily and when she was satisfied I was drained dry, she sat back in her seat and giggled. "Now that was hot," she said. I could only nod, my mouth had gone dry.

I started to pull my scrub pants back up and Astrid objected..."I'm naked, why don't you do the same? Besides, I may want to suck it again before we get home." I started wondering who was this woman, in our fifteen years together, she had never displayed this level of eroticism or lust. So, the scrub bottoms came off and ended up on the back floorboard, the top came off next and went to the same place.

Astrid began playing with my cock with her left hand was playing with herself with her right. When we got to Harmony Road, I asked her to stop playing with my cock, it takes all of my concentration to drive that switchback to the top of the mountain. Astrid reluctantly let my cock go and laid back in her seat and sighed contentedly as she brought herself to another orgasmed. I damn near had an orgasm myself. Now right at the top of Harmony Road is where our driveway doglegs back to the left. I pulled in and began to drive slowly to the house. Astrid asked me, "Did you ever want to fuck my ass?" All I could do was nod eagerly. Astrid giggled again, "Well, you can tonight, as many times as you want." We made it to the house hand in hand and made it as far as the living room sofa. Three minutes later my cock was buried in her ass, I fucked her long and slow until I blew my load deep inside her ass, and just as I did, Astrid had another orgasm. We showered together and fell into bed, exhausted and wrapped up in each other's arms. The next five days we explored a few different things and spent them naked. Astrid walked to the mailbox naked, I jerked off on the front porch while she watched. We talked about her new found freedoms so to speak, she said she realized as of late how short life was for a number of reasons, all of them jobrelated. So, now we play at every chance 
(C) This work is licensed under Creative Commons Attribution 4.0 License

DOI: $10.19080 / J O J N H C .2018 .06 .555686$

\section{Your next submission with Juniper Publishers} will reach you the below assets

- Quality Editorial service

- Swift Peer Review

- Reprints availability

- E-prints Service

- Manuscript Podcast for convenient understanding

- Global attainment for your research

- Manuscript accessibility in different formats

( Pdf, E-pub, Full Text, Audio)

- Unceasing customer service

Track the below URL for one-step submission https://juniperpublishers.com/online-submission.php 